Www.jmscr.igmpublication.org

Impact Factor (SJIF): 6.379

Index Copernicus Value: 79.54

ISSN (e)-2347-176x ISSN (p) 2455-0450

crossrefDOI: https://dx.doi.org/10.18535/jmscr/v6i10.106

Journal Of Medical Science And Clinical Research

IGM Publication

An Official Publication of IGM Publication

\title{
Patient Knowledge of Conservative Management of Symptomatic Knee Osteoarthritis at Orthopedic Clinic, in SFHP, Riyadh (A Primary Health Care Prospective)
}

\author{
Authors \\ Anfal Mohammad Aljohani ${ }^{1}$, Medhat A Ghoraba ${ }^{2}$ \\ ${ }^{1}$ Family Medicine Resident \\ ${ }^{2} \mathrm{MBBCH}$, MSC, FRACGP, FARGP, DipRGP \\ Consultant Family Medicine, SFHP \\ Adj. Lecturer Flinders University, AUS \\ Adj.Ass.Prof.FM, UAE University \\ Ass. Prof.Al-Faisal University, KSA \\ Email:mghoraba@sfh.med.sa
}

\begin{abstract}
Background: Knee osteoarthritis is a joint disease that is either symptomatic or asymptomatic. Changes in structures in and around knee joint occurs in this condition. This disease is more dominant in females than in males, the prevalence also is increasing with increased age and presence of obesity. Knee osteoarthritis is managed by non-operative treatment options such as exercise and analgesics in primary care.

Aim: To assess patient knowledge about non operative treatment of symptomatic knee osteoarthritis provided in family medicine department.

Method: This study is cross sectional descriptive study, it was conducted between the periods from $1^{\text {st }}$ May 2017 to $1^{\text {st }}$ December 2017 on symptomatic knee OA patients who were visiting the orthopedic clinic at family medicine department in Security Forces Hospital. The study was performed using questionnaire. All Statistical analysis was perform using SAS version 9.2 (SAS Institute, Inc, Cary, NC).

Results: $43.6 \%$ of patients knew about conservative management for knee OA, weight reduction was the most common strategy known by patients (95.1\%), followed by physiotherapy (77\%), and then pain killer (45.9\%). $94.3 \%$ of patients used pain killer, $51.4 \%$ used weight reduction, $75.7 \%$ used physiotherapy and $25 \%$ used intra-articular injections.

Conclusion: There was low knowledge of patients about knee OA conservative management, several demographics and co-morbidities were associated with the level of knowledge. Patients had negative attitude to family physicians regarding their treatment.

Keywords: Knee OA management, Knowledge, Knee OA patients, Family physicians.
\end{abstract}

\section{Introduction}

Osteoarthritis (OA) is a chronic common condition which causes functional limitations, fatigue, pain and increased health care utilization
[1]. Knee OA is a joint disease form that is prevalent in both symptomatic and radio graphically evident ${ }^{[2]}$. It involves changes in structures in and around knee joint, the dominant 
changes including the formation of osteophytes and loss of cartilage ${ }^{[3]}$. Also, articular and periarticular soft tissue changes occur in Knee OA such as joint effusions ${ }^{[4]}$ and synovial hyperplasia ${ }^{[5]}$. Knee OA is less prevalent in males $(6.8 \%)$ than in females $(11.4 \%)^{[6]}$. The prevalence of $\mathrm{OA}$ is increasing as a result of population aging and increased obesity ${ }^{[7]}$. The definite cause of OA is unknown, however there are risk factors for OA including systemic and local biochemical factors. The systemic factors including gender, overweight, age and genetics, whereas local biochemical factors involving muscle weakness, joint injury and malalignment, moreover the biochemical cascade can be activated by mechanical load ${ }^{[8]}$. Clinical Knee OA is managed by non pharmacological options such as exercise and analgesics in primary care ${ }^{[9,10]}$. Exercise was found to improve walking speed, function, strength and self-efficacy, also it reduce the risk of other chronic conditions, pain and progression of the disease ${ }^{[11-13]}$.

\section{Literature review}

The management of OA aims to control pain and reduce functional limitations, the management involves pharmacologic and non pharmacologic modalities ${ }^{[2]}$. Conservative non pharmacological treatment are the primary option for OA patients ${ }^{[14,15]}$, as the clinical guidelines for knee OA recommended it as the first line of management [16]. Non pharmacological therapy includes education of patient about the disease nature, the benefits and risks of different treatment options $^{[17]}$. Treatment strategy also involves using of heat and cold as safe and low cost option which can be used either solely or in combination with other treatments for Knee $\mathrm{OA}^{[18]}$. Therapeutic exercises have shown effectiveness for Knee $\mathrm{OA}^{[19]}$. Exercises are prescribed for Knee OA patients as they slow and minimize the pathological process of OA by modifying possible risk factors of disease progression, reduce the impairment caused by OA, reduce pain ${ }^{[2]}$. The pharmacological systemic treatment of knee OA involves using of NSAIDs, opoids, oral paracetamol and intra-articular corticosteroids injections $^{[20]}$. Insufficient knowledge can act as a potential barrier for $\mathrm{OA}$ care and selfmanagement ${ }^{[21]}$. Alami et al, conducted qualitative study based on semi-structured interviews of a stratified sample of 81 patients in France and found that patients of knee $\mathrm{OA}$ had negative perception of drugs which resulted in low compliance with treatment ${ }^{[22]}$. OA patients should be empowered to manage the disease and its symptoms ${ }^{[23]}$. Patients need sufficient knowledge to understand the nature of the disease and the treatment options to make their decisions and cope with their condition ${ }^{[24]}$. Little is known about the knowledge of patients regarding non operative management of symptomatic knee OA, so we conducted the current study.

\section{Patients \& Methods \\ Subjects and study design}

This study is cross sectional descriptive study which was conducted between the period from $1^{\text {st }}$ May 2017 to $1^{\text {st }}$ December 2017 on symptomatic knee OA patients who were visiting the orthopedic clinic at family medicine department in Security Forces Hospital, Riyadh, Saudi Arabia.

The inclusion criteria were:

- Saudi patients

- age 35 years and older

- Patient referred from family medicine to a specialized orthopedic clinic.

The exclusion criteria were:

- non Saudi patients

- asymptomatic knee OA

- patients booked for surgical treatment

\section{Sample Size and Technique}

Using expected prevalence of Knee Osteoarthritis is $24.88 \%$ as $50 \%$ as given in literature for calculating our sample size. Under the simple random sampling with margin of error at $5 \%$ and the confidence level at $95 \%$, we needed a sample of size 246. Allowing for $15 \%$ non-response rate the final required sample size is 283 . 
We used the following formula $n=z 2(1-p) d 2$

Where $n=$ sample size, $\mathrm{z}=\mathrm{z}$ statistic for the level of confidence, $\mathrm{P}=$ expected prevalence and $\mathrm{d}=$ allowable error. This formula assumes that "P" and "d" are decimal values.

\section{Statistical Analysis}

Numbers and percentages were used to summarize categorical/qualitative. Where numeric/ quantitative data were summarized by means and standard deviations for normal data and medians and inter quartile ranges for nonnormal data. Comparison between groups for categorical variables was done using chi-square or Fisher's exact test. We used t-test or MannWhitney $\mathrm{U}$ test for comparison between groups for quantitative variables for two groups and analysis of variance (ANOVA) or Kruskal-Wallis $\mathrm{H}$ test for three or more groups. To identify risk factor or to estimate the adjusted association we used logistic regression models. All Statistical analysis was perform using SAS version 9.2 (SAS Institute, Inc, Cary, NC).

\section{Results}

The present study included 283 knee OA patients, the demographics of patients were as in table (1); the patients'age range was 42-72 years old with a mean \pm SD of $57.7 \pm 8$ years. Females were more dominant than males $75 \%$ and $25 \%$ respectively. $40 \%$ of patients had secondary education, $32.1 \%$ had high school education, $18.6 \%$ and $9.3 \%$ were illiterate and had primary education respectively. There were $44.3 \%$ of patients housewives, 39.3\% were retired and $16.4 \%$ only were working. The majority $80.7 \%$ were married, while $15 \%$ and $4.3 \%$ were widow and divorced respectively. The weight of patients ranged from $86-115 \mathrm{Kg}$ with a mean of $89.3 \pm 11.5 \mathrm{Kg}$, while the height range was $145-181 \mathrm{Cm}$ with a mean of $159.4 \pm 9.3 \mathrm{Cm}$. The range BMI of participants was 23.6-45.3 with a mean of $35.3 \pm 4.6$. There were $38.6 \%$ of patients reported that they had family history of knee OA, while 53.5\% didn't know that and 7.9\% didn't have family history. Most of patients $57.8 \%$ reported having symptoms for3-5 years, whereas $28.6 \%$ reported less than 3 years and $13.6 \%$ reported more than 5 years. Patients were investigated for co-morbidities they were suffering, $67.9 \%$ of patients reported having chronic diseases, $47.1 \%$ and $32.1 \%$ reported suffering hypertension and dyslipidemia respectively, there were $20 \%$ suffering diabetes mellitus, $12.1 \%$ suffering cardiovascular disease and $4.3 \%$ only had obesity. Table1 \&figures1-6 summarize the demographics and clinical characteristics of patients.

Table1: Demographics and clinical characteristics of patients

\begin{tabular}{|l|c|}
\hline Demographics and clinical characteristics & $\%$ \\
\hline Age & \\
Range & $42-72$ \\
Mean \pm SD & $57.7 \pm 8$ \\
\hline Gender & \\
Male & 25 \\
Female & 75 \\
\hline Educational level & 18.6 \\
Illiterate & 9.3 \\
Primary school & 40 \\
Secondary school & 32.1 \\
High school & \\
\hline Occupation & 16.4 \\
Employed & 39.3 \\
Retired & 44.3 \\
Housewives & \\
\hline Marital status & 80.7 \\
Married & 4.3 \\
Divorced & 15 \\
Widow & \\
\hline Weight & $68-115$ \\
Range & $89.3 \pm 11.5$ \\
\hline Mean \pm SD & \\
\hline Height & $145-181$ \\
Range & $159.4 \pm 9.3$ \\
Mean \pm SD & $23.6-45.3$ \\
\hline BMI & $35.3 \pm 4.6$ \\
Range & 38.6 \\
Mean \pm SD & 7.9 \\
\hline Family history of knee Osteoarthritis & 53.5 \\
Yes & 28.6 \\
No & 57.8 \\
I don't know & 13.6 \\
\hline How long have you had symptoms of osteoarthritis \\
<3 years & \\
3-5 years & \\
>5 years & \\
\hline Co-morbidities & \\
Chronic diseases & \\
Hypertension & \\
Dyslipidemia & \\
Diabetes mellitus & \\
Cardio vascular disease & \\
Obesity & \\
\hline
\end{tabular}




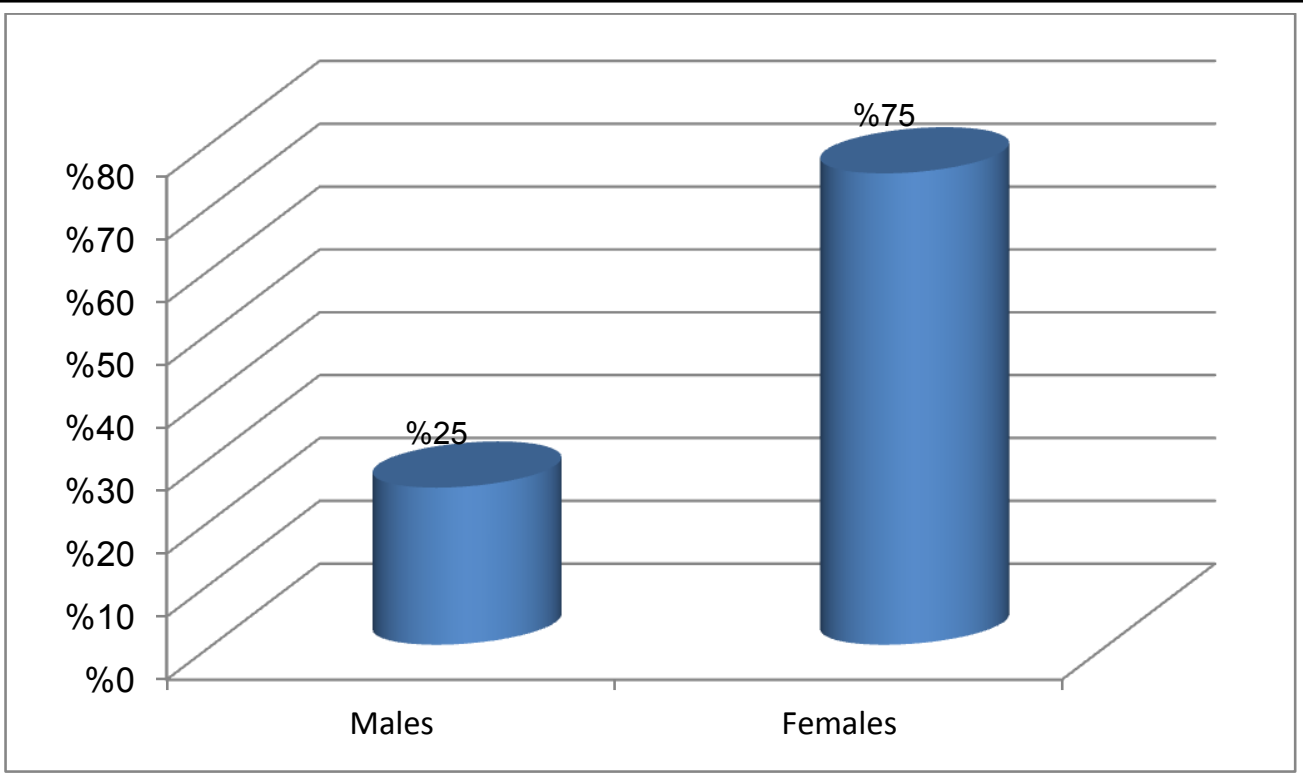

Fig 1: Gender distribution

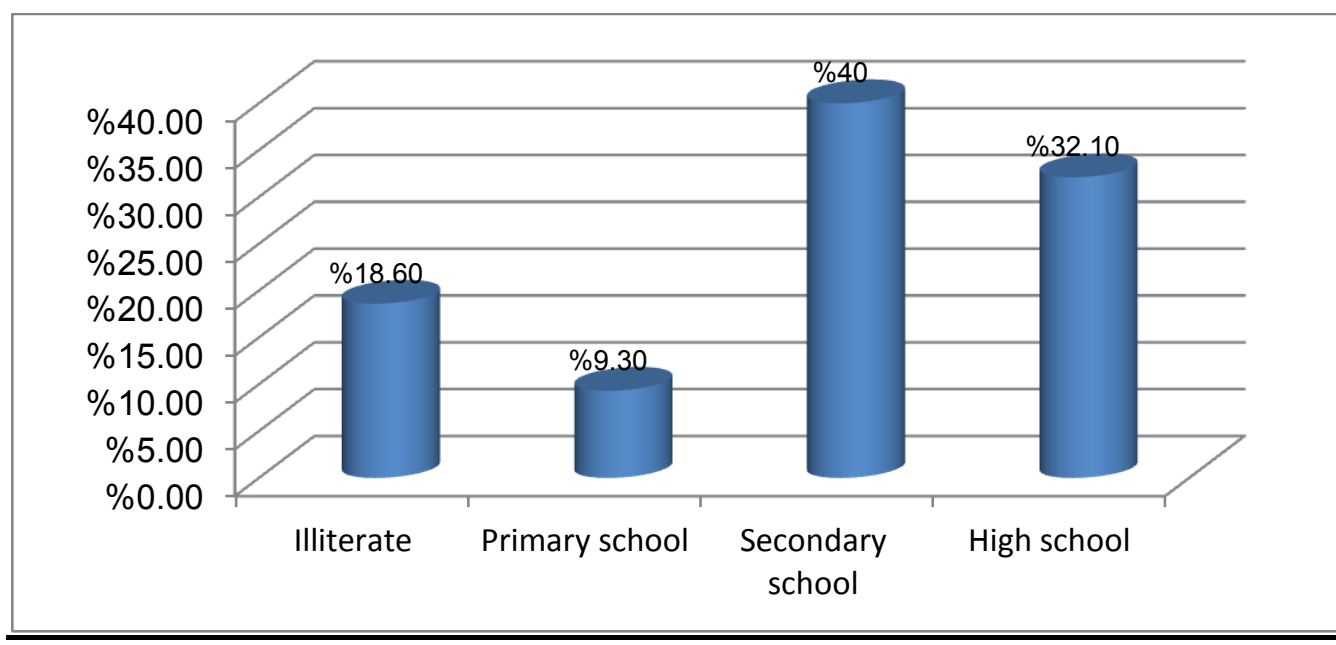

Fig 2: Educational level of patients

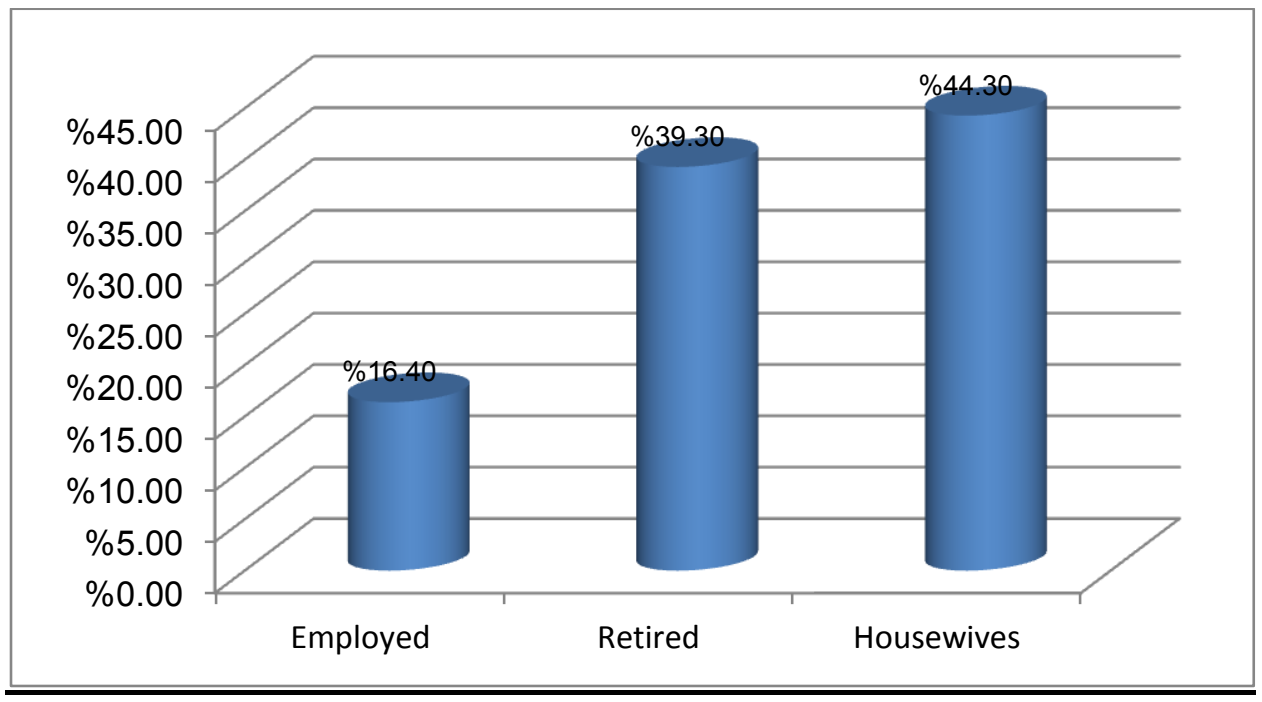

Fig 3: Occupation of patients 


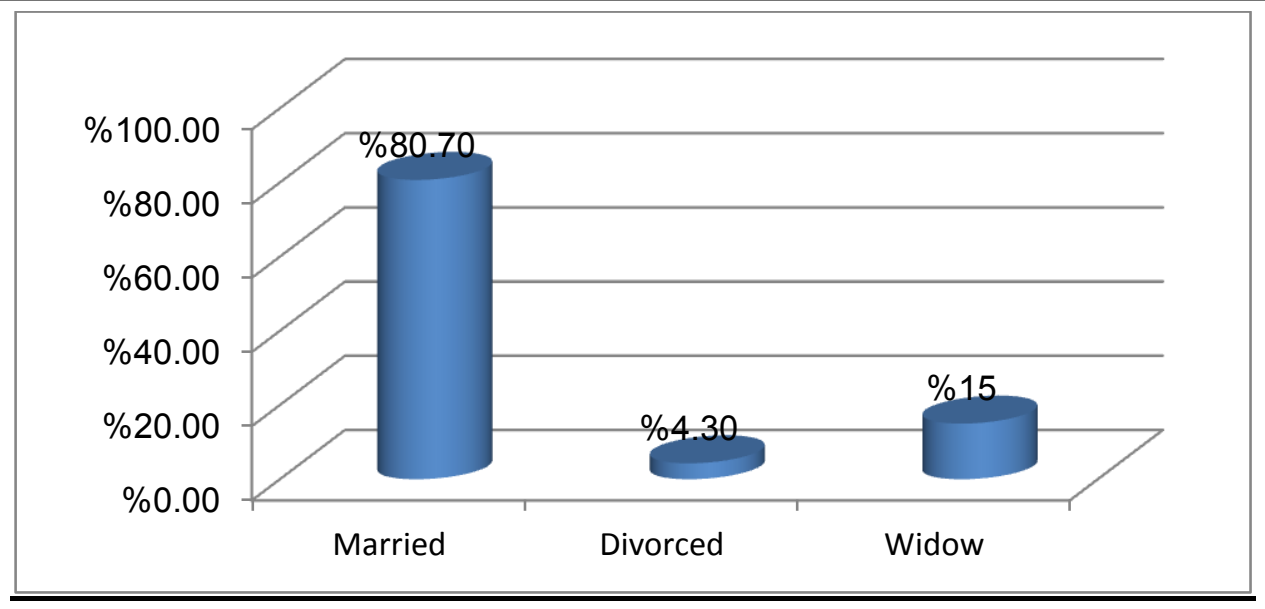

Fig 4: Marital status of patients

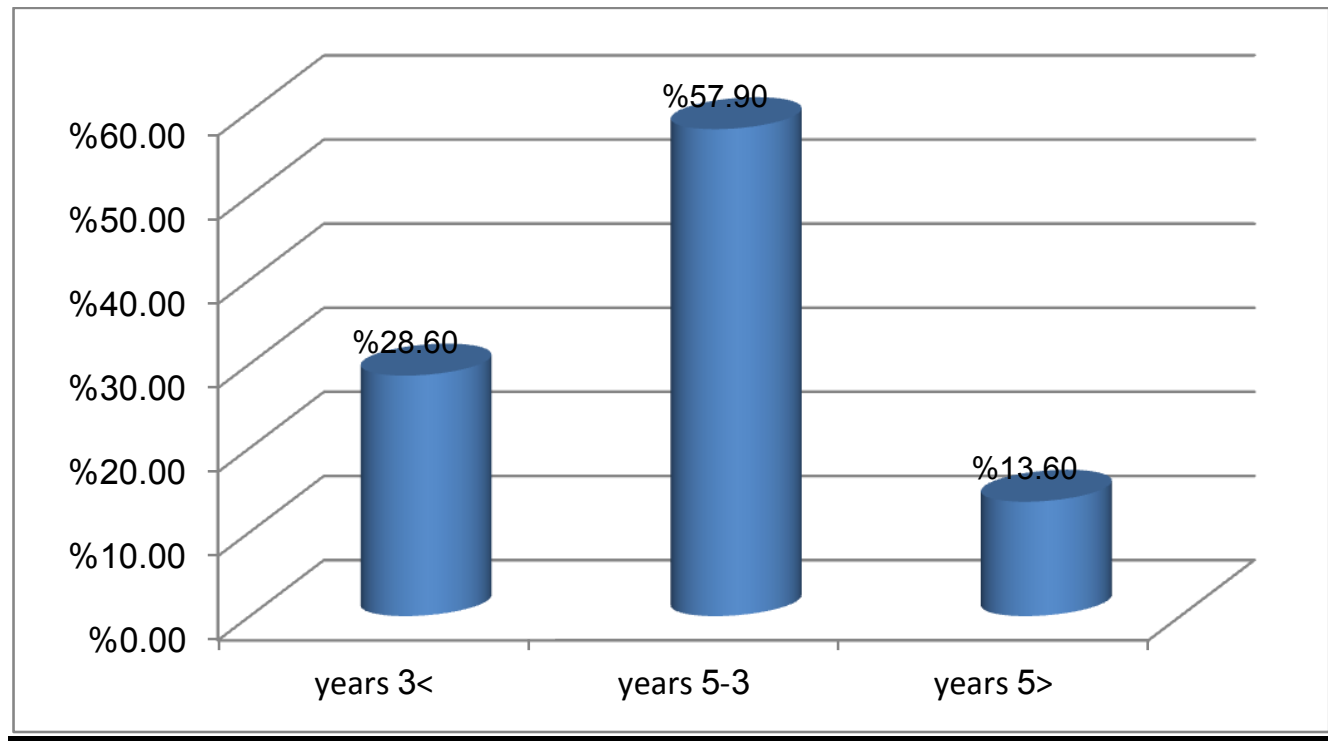

Fig 5: Duration of symptoms of OA

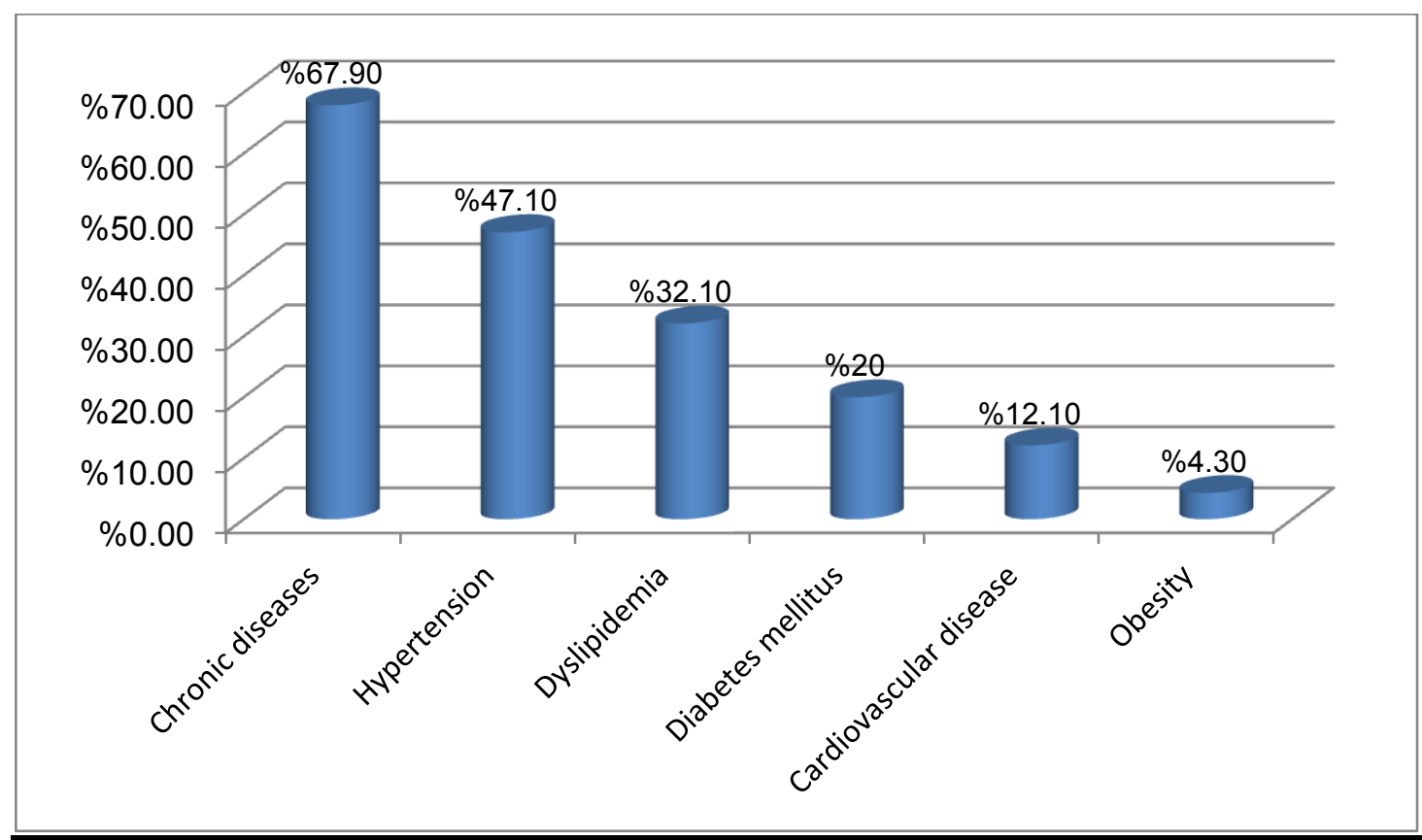

Fig 6: Co-morbidities of patients 
The knowledge regarding conservative management for knee OA involved knowledge about presence of conservative management and type of it. Almost forty four percent (43.6\%) of patients reported presence of conservative management for knee OA, (figure7). The knowledge regarding type of conservative treatment is shown in figure 8 , knowledge about weight reduction was the most among patients (95.1\%), followed by knowledge about physiotherapy (77\%) and the pain killer (45.9\%), there was no one knew about intra-articular injection $(0 \%)$.

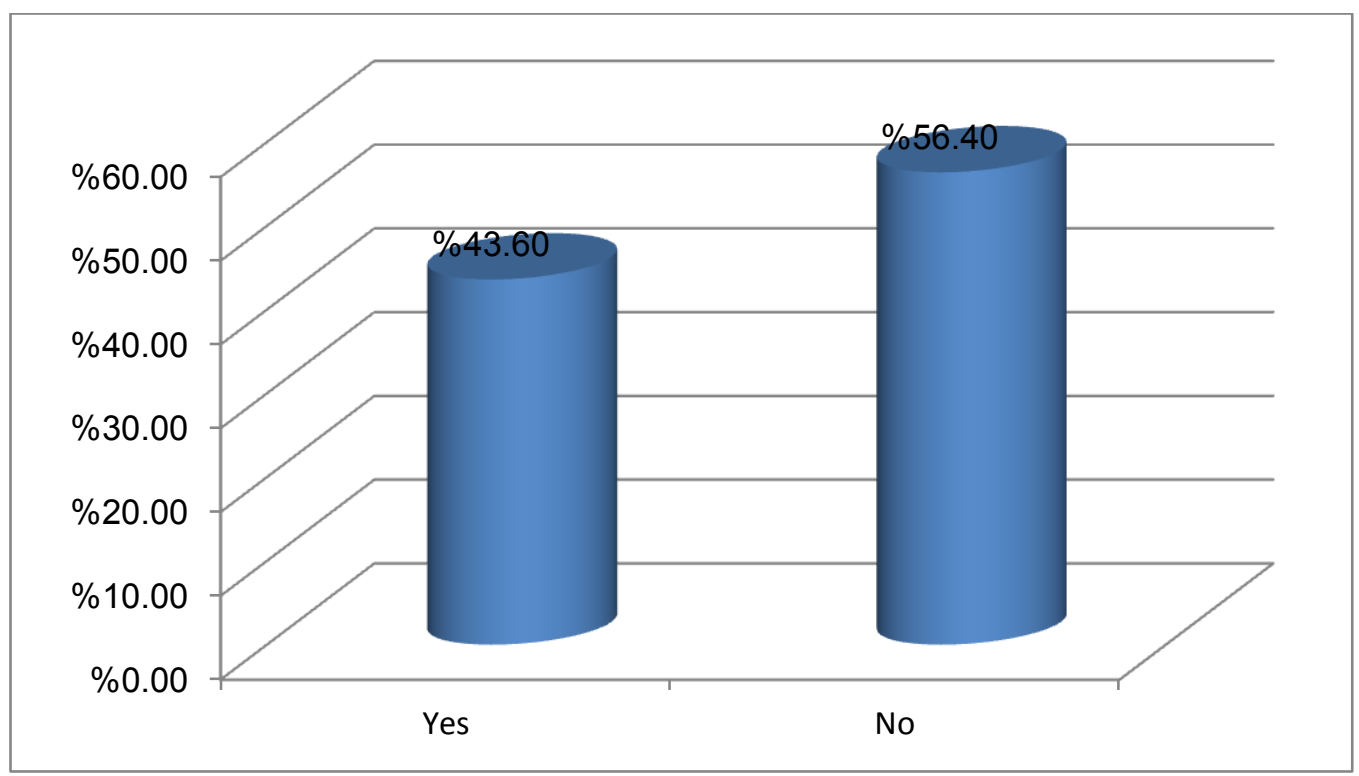

Fig 7: knowledge of patients about presence of conservative management for knee OA

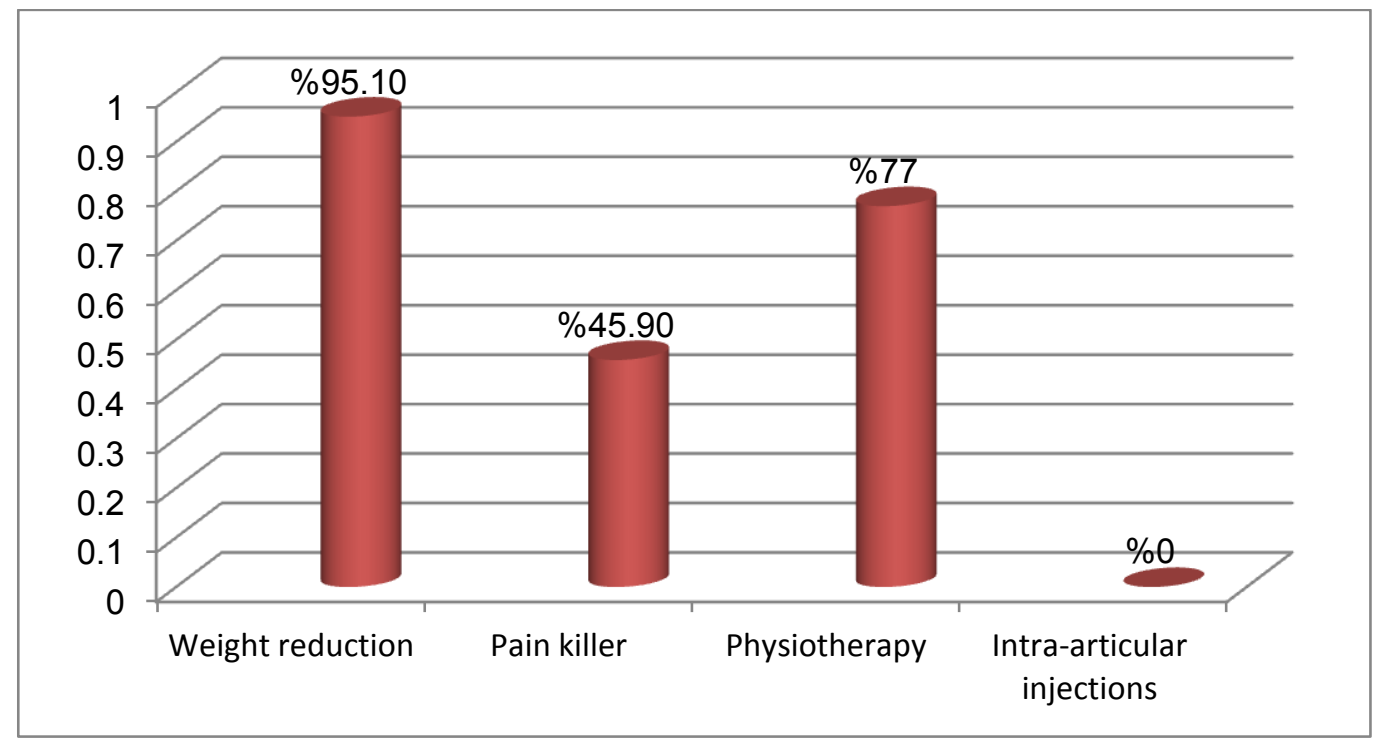

Fig 8: Knowledge of patients about types of conservative management

Attitude of patients regarding family physicians treatment knee OA was investigated (table 2), where $79.3 \%$ of patients stated that physicians can't treat knee OA, and $10.3 \%$ reported that physicians gave them options of conservative management for knee OA. There were $30 \%$ of patients confirmed that they visited their family physicians more than once complaining of the knee pain and $70 \%$ said that family physicians referred them to orthopedics without trying using of conservative management, attitude of patients is shown in table 2. Regarding practice of 
conservative management, $94.3 \%$ reported using pain killer medication, $97.7 \%$ of them used Paracetamol, $40.2 \%$ used NSAIDs, $2.3 \%$ used Opoids. $60 \%$ of patients said they used pain killer for more than 1 time, $31.4 \%$ said more than 5 times and $8.6 \%$ said more than 10 times. $58.3 \%$ of patients reported that pain killer didn't improve the pain, while $41.7 \%$ said it improved the pain, table3

Table 2: Attitude of patients toward family physicians regarding conservative management

\begin{tabular}{|c|c|}
\hline & $\%$ \\
\hline $\begin{array}{l}\text { Family physician can treat knee osteoarthritis } \\
\text { Yes } \\
\text { No }\end{array}$ & $\begin{array}{l}20.7 \\
79.3\end{array}$ \\
\hline $\begin{array}{l}\begin{array}{l}\text { Family physician give you any options of } \\
\text { conservative } \\
\text { management for knee } \\
\text { osteoarthritis before }\end{array} \\
\text { Yes } \\
\text { No } \\
\end{array}$ & $\begin{array}{r}10.3 \\
89.7 \\
\end{array}$ \\
\hline $\begin{array}{l}\text { Did you visit your family physician more than } \\
\text { once complaining of the knee pain before he/she } \\
\text { referred you to orthopedics } \\
\text { Yes } \\
\text { No }\end{array}$ & $\begin{array}{l}30 \\
70\end{array}$ \\
\hline $\begin{array}{l}\text { Did your family physician refer you to } \\
\text { orthopedics without trying with you } \\
\text { conservative management } \\
\text { Yes } \\
\text { No }\end{array}$ & $\begin{array}{l}70 \\
30\end{array}$ \\
\hline
\end{tabular}

Table 3: Practice of different of conservative management

\begin{tabular}{|c|c|}
\hline Variables & $\%$ \\
\hline $\begin{array}{l}\text { Tried pain killer medications before } \\
\text { Yes } \\
\text { No }\end{array}$ & $\begin{array}{c}94.3 \\
5.7\end{array}$ \\
\hline $\begin{array}{l}\text { Kind of pain killer medications tried before } \\
\text { Paracetamol } \\
\text { NSAIDs } \\
\text { Opioids } \\
\end{array}$ & $\begin{array}{c}97.7 \\
40.2 \\
2.3 \\
\end{array}$ \\
\hline $\begin{array}{l}\text { How many times used } \\
\text { More than } 1 \\
\text { More than } 5 \\
\text { More than } 10 \\
\end{array}$ & $\begin{array}{c}60 \\
31.4 \\
8.6\end{array}$ \\
\hline $\begin{array}{l}\text { Is pain improved by pain killers } \\
\text { Yes } \\
\text { No }\end{array}$ & $\begin{array}{l}41.7 \\
58.3\end{array}$ \\
\hline $\begin{array}{l}\text { Tried Weight reduction } \\
\text { Yes } \\
\text { No }\end{array}$ & $\begin{array}{l}51.4 \\
48.6 \\
\end{array}$ \\
\hline $\begin{array}{l}\text { How much weight did you reduce } \\
\text { Range } \\
\text { Mean } \pm \text { SD }\end{array}$ & $\begin{array}{c}1-14 \\
4.9 \pm 3.7\end{array}$ \\
\hline $\begin{array}{l}\text { Is pain improved by weight reduction } \\
\text { Yes } \\
\text { No }\end{array}$ & $\begin{array}{l}70.8 \\
29.2\end{array}$ \\
\hline $\begin{array}{l}\text { Tried physiotherapy before } \\
\text { Yes } \\
\text { No }\end{array}$ & $\begin{array}{l}75.7 \% \\
24.3 \%\end{array}$ \\
\hline
\end{tabular}

\begin{tabular}{|l|c|}
\hline For how many times & 0 \\
1 & 50 \\
$2-5$ & 41.2 \\
$5-10$ & 8.8 \\
More than 10 times & \\
\hline Is pain improved by physiotherapy & 62.3 \\
Yes & 37.7 \\
No & \\
\hline Tried Intraarticular injections before & 25 \\
Yes & 75 \\
No & \\
\hline For how many times & 40 \\
1 & 34.3 \\
2 & 17.1 \\
3 & 8.6 \\
4 & \\
\hline Is pain improved by Intraarticular & \\
injections & 17.1 \\
Yes & 82.9 \\
no &
\end{tabular}

Different variables were investigated if they influenced the knowledge of patients or not, older age was significantly associated with lower knowledge $(\mathrm{P}$-value $<0.001)$. Being illiterate and having primary school were significantly associated with less knowledge ( $\mathrm{P}$-value $<0.001$, $=0.001$ respectively), whereas having high school was significantly associated with high knowledge (P-value $<0.001)$. Occupation was significantly associated with the level of patients' knowledge, retired patients were of higher knowledge than others. Married patients significantly tended to have higher knowledge (P-value $=0.01$ ), whereas divorced ones tended to have less knowledge ( $\mathrm{P}$ value $=0.03)$. Height, BMI and different comorbidies significantly associated with the knowledge level, having chronic diseases, hypertension, dyslipidemia, diabetes mellitus significantly tended to have less knowledge. Patients weight and obesity had no influence on patients knowledge (P-value $>0.05)$. Family history didn't influence the knowledge, except for those who didn't know any information about family history, they significantly tended to have less knowledge (P-value=0.02). Having OA symptoms for a period less than 5 years was significantly associated with the level of knowledge (P-value $<0.001$ ), having symptoms for less than 3 years was associated with high knowledge, while having symptoms for 3-5 years was associated with less knowledge. 
Table 4: Factors affecting Knowledge regarding conservative management for knee osteoarthritis

\begin{tabular}{|c|c|c|c|}
\hline \multirow[b]{2}{*}{ Variables } & \multicolumn{2}{|c|}{$\begin{array}{l}\text { Knowledge regarding conservative management } \\
\text { for knee osteoarthritis }\end{array}$} & \multirow{2}{*}{$P$ value } \\
\hline & $\begin{array}{l}\text { Know } \\
43.6 \%\end{array}$ & $\begin{array}{l}\text { Do not know } \\
56.4 \%\end{array}$ & \\
\hline Age & $53.9 \pm 7.7$ & $60.7 \pm 7$ & $<0.001$ \\
\hline $\begin{array}{l}\text { Gender } \\
\text { Male } \\
\text { Female }\end{array}$ & $\begin{array}{l}32.8 \% \\
67.2 \%\end{array}$ & $\begin{array}{l}19 \% \\
81 \%\end{array}$ & 0.062 \\
\hline $\begin{array}{l}\text { Educational Level } \\
\text { Illiterate } \\
\text { Primary school } \\
\text { Secondary school } \\
\text { High school }\end{array}$ & $\begin{array}{c}4.9 \% \\
0 \% \\
37.7 \% \\
57.4 \% \\
\end{array}$ & $\begin{array}{l}29 \% \\
16.5 \% \\
41.8 \% \\
12.7 \%\end{array}$ & $\begin{array}{c}<\mathbf{0 . 0 0 1} \\
\mathbf{0 . 0 0 1} \\
0.728 \\
<\mathbf{0 . 0 0 1}\end{array}$ \\
\hline $\begin{array}{l}\text { Occupation } \\
\text { Employed } \\
\text { Retired } \\
\text { Housewives } \\
\end{array}$ & $\begin{array}{l}31.1 \% \\
54.1 \% \\
14.8 \% \\
\end{array}$ & $\begin{array}{c}5.1 \% \\
27.8 \% \\
67.1 \% \\
\end{array}$ & $\begin{array}{c}<0.001 \\
0.002 \\
<0.001 \\
\end{array}$ \\
\hline $\begin{array}{l}\text { Marital status } \\
\text { Married } \\
\text { Divorced } \\
\text { Widow } \\
\end{array}$ & $\begin{array}{c}90.2 \% \\
0 \% \\
9.8 \%\end{array}$ & $\begin{array}{c}73.4 \% \\
7.6 \% \\
19 \% \\
\end{array}$ & $\begin{array}{l}\mathbf{0 . 0 1 7} \\
\mathbf{0 . 0 3 6} \\
0.157\end{array}$ \\
\hline Weight & $90.6 \pm 13.1$ & $88.3 \pm 9.9$ & 0.287 \\
\hline Height & $162.7 \pm 10$ & $156.7 \pm 7.9$ & $<0.001$ \\
\hline BMI & $34.3 \pm 4.5$ & $36.1 \pm 4.5$ & 0.043 \\
\hline Chronic diseases & $39.3 \%$ & $89.9 \%$ & $<0.001$ \\
\hline Hypertension & $29.5 \%$ & $60.8 \%$ & $<0.001$ \\
\hline Dyslipidemia & $9.8 \%$ & $49.4 \%$ & $<0.001$ \\
\hline Diabetes mellitus & $9.8 \%$ & $27.8 \%$ & 0.008 \\
\hline Cardio vascular disease & $9.8 \%$ & $13.9 \%$ & 0.463 \\
\hline Obesity & $4.9 \%$ & $3.8 \%$ & 0.745 \\
\hline $\begin{array}{l}\text { Family history of knee } \\
\text { Osteoarthritis } \\
\text { Yes } \\
\text { No } \\
\text { I don't know } \\
\end{array}$ & $\begin{array}{c}47.6 \% \\
9.8 \% \\
42.6 \% \\
\end{array}$ & $\begin{array}{c}31.6 \% \\
6.4 \% \\
62 \%\end{array}$ & $\begin{array}{l}0.080 \\
0.533 \\
\mathbf{0 . 0 2 7}\end{array}$ \\
\hline $\begin{array}{l}\text { How long have you had } \\
\text { symptoms of osteoarthritis } \\
<3 \text { years } \\
3-5 \text { years } \\
>5 \text { years }\end{array}$ & $\begin{array}{c}52.5 \% \\
37.7 \% \\
9.8 \% \\
\end{array}$ & $\begin{array}{l}10.1 \% \\
73.4 \% \\
16.5 \%\end{array}$ & $\begin{array}{c}<\mathbf{0 . 0 0 1} \\
<\mathbf{0 . 0 0 1} \\
0.321 \\
\end{array}$ \\
\hline
\end{tabular}

\section{Discussion}

The present study was conducted to assess the knowledge of knee OA patients about the conservative management. There was a low level of knowledge regarding the presence of conservative management for knee OA, only $43.6 \%$ knew about it, whereas $56.4 \%$ had no knowledge. Weight reduction was the most type of conservative therapy known by patients (95.1\%) followed by physiotherapy, no one knew about intra-articular injections. Several factors influenced knowledge of patients, including age, educational level, occupation, marital status, weight, BMI, several co-morbidities, family history and duration of suffering OA symptoms.

However, each factor of this significantly associated either with high knowledge or low knowledge. Older age, low education, being housewife, divorced, lower height, high BMI, chronic diseases, hypertension, dyslipidemia, diabetes mellitus, being unaware of family history of OA and symptoms lasting for 3-5 years were associated with low knowledge. Other factors were associated with high knowledge including, higher education, being retired, married and less than3 years suffering symptoms. There was no 
previous studies done in other countries similar to ours, so we couldn't compare our results with previous ones. In the current study, although $45.9 \%$ only knew about pain killer, there were $94.3 \%$ tried it before for treatment and the most commonly used one was Paracetamol (97.7\%), however only $41.7 \%$ reported that pain killer improved their pain. There were only 51.4 $\%$ patients tried weight reduction, the mean of weight reduced by patients was $4.9 \mathrm{Kg}$, however higher percent $70.8 \%$ reported that the weight reduction reduced pain. Higher percent $(75.7 \%)$ tried physiotherapy, half of them tried it at least 2 times and $62.3 \%$ reported the efficiency of physiotherapy in pain improvement. The least percent of patients (25\%) reported trying intraarticular injections, and only $17.1 \%$ reported improvement by this strategy. The present study revealed that the most used type of conservative management was pain killer, but the most efficient one was weight reduction. It was stated that improving pain of patients can be done by pharmacological agents such as paracetamol, however, it was reported that the majority of patients preferred NSAIDs to paracetamol ${ }^{[20]}$. It was found that weight loss improves pain and function as obesity is a risk factor for developing knee OA and weight reduction is the key for effective primary and secondary disease prevention strategy ${ }^{[2]}$. Physiotherapy is a conservative non-pharmacological approach which include taping, supervised exercise programs, manual therapy, hydrotherapy and bracing $^{[25]}$. It was found that physical activity was beneficial, but, it resulted in small to moderate effect on knee OA patients ${ }^{[26]}$. Regarding attitude of patients to family physicians toward their treatment, there were low attitude, where few percent thought that physician can treat OA $(20.7 \%)$, the majority $(89.7 \%)$ denied that family physicians gave them options for conservative treatment, $70 \%$ reported that physicians referred them to orthopedics without trying conservative management. A study from France reported similar findings regarding attitude and patient to physician relation, it was found that patients felt that their complains aren't taken seriously, and practitioner gave more attention to the knee than the patient and they act as technicians and no enough time spent on counseling and information $^{[22]}$. It is very recommended to establish further study about this subject, as patients had low knowledge about the conservative management and negative attitude to family physicians.

\section{Conclusion}

There was low knowledge of patients about knee OA conservative management, the highest knowledge was regarding weight reduction and it also was the most effective strategy to improve pain, however pain killer was the most commonly used. Patients had negative attitude to family physicians regarding their treatment.

\section{Strength and limitations of the study}

The strength points in this study include the novelty of the subject as no previous study investigate the knowledge of patients about knee OA management, as well as their attitude and practice, the sample size was convenient, the limitations of the study is the lack of comparison as no previous study was found to be similar to ours, so it is recommended to conduct further researches on this subject with larger sample size.

\section{Acknowledgment}

First of all, I would like to thank my supervisor Dr. Medhat A Ghoraba who have been supportive of my research and my academic goals

This work would not have been possible without my family support. I would like to thank my parents, whose love and support me in whatever I pursue. Most importantly, I wish to thank my loving and supportive husband, for his continued support and encouragement.

Finally I can't forget my entire colleague on Family Medicine Program for their Support. 


\section{References}

1. Litwic A, Edwards MH, Dennison EM, Cooper C. Epidemiology and burden of osteoarthritis. Br Med Bull. 2013; 105: 185-199.

2. Hafez AR, Alenazi AM, Kachanathu SJ, Alroumi AM, Mohamed ES. Knee Osteoarthritis: A Review of Literature. Phys Med Rehabil Int. 2014;1(5): 8.

3. KELLGREN JH, LAWRENCE JS. Radiological assessment of osteo-arthrosis. Ann Rheum Dis. 1957; 16: 494-502.

4. de Miguel Mendieta E, Cobo Ibáñez T, Usón Jaeger J, Bonilla Hernán G, Martín Mola E . Clinical and ultrasonographic findings related to knee pain in osteoarthritis. Osteoarthritis Cartilage. 2006; 14: 540-544.

5. Kristoffersen H, Torp-Pedersen S, Terslev L, Qvistgaard E, Holm CC, Ellegaard K, et al. Indications of inflammation visualized by ultrasound in osteoarthritis of the knee. Acta Radiol. 2006; 47: 281-286.

6. Felson DT, Naimark A, Anderson J, Kazis L, Castelli W, Meenan RF. The prevalence of knee osteoarthritis in the elderly. The Framingham Osteoarthritis Study. Arthritis Rheum. 1987; 30: 914-918.

7. Srikanth VK, Fryer JL, Zhai G, Winzenberg TM, Hosmer D, Jones G . A meta-analysis of sex differences prevalence, incidenceand severity of osteoarthritis. Osteoarthritis Cartilage. 2005; 13: 769-781.

8. Nuki G, Salter D. The impact of mechanical stress on the pathophysiology of osteoarthritis. In :Sharma L \& Berenbaum F (eds). Osteoarthritis. Philadelphia: Mosby;2007: pp.33-52.

9. Neil A Segal, James Torner, David Felson, Jingbo Niu, Leena Sharma, Cora E. Lewis, et al.: The Effect of Thigh Strength on Incident Radiographic and Symptomatic Knee Osteoarthritis in the Multicenter Osteoarthritis (MOST) Study, Arthritis
Rheum. 2009 September 15; 61: 12101217.

10. Lane NE, Thompson JM. Management of osteoarthritis in the primary-care setting: an evidence-based approach to treatment. Am J Med. 1997; 103: 25S-30S.

11. Foster NE, Thomas E, Barlas P, Hill JC, Young J, Mason E, et al . Acupuncture as an adjunct to exercise based physiotherapy for osteoarthritis of the knee: randomised controlled trial. BMJ. 2007; 335: 436.

12. Melanie A Holden, Elaine E Nicholls, Elaine M Hay, Nadine E Foster: Physical Therapists' Use of Therapeutic Exercise for Patients With Clinical Knee Osteoarthritis in the United Kingdom: In Line With Current Recommendations?, Phys Ther. 2008 October; 88(10): 1109 1121.

13. Losina E, Weinstein AM, Reichmann WM, Burbine SA, Solomon DH, Daigle $\mathrm{ME}$, et al. Lifetime risk and age at diagnosis of symptomatic knee osteoarthritis in the US. Arthritis Care Res (Hoboken). 2013; 65: 703-711.

14. Hochberg M.C., Altman R.D., April K.D., Benkhalt M., Guyatt G., McGowan J., Towheed T., Welch V., Wells G. \& Tugwell P. American College of Rheumatology 2012 recommendations for the use of no pharmacologic and pharmacologic therapies in osteoarthritis of the hand, hip and knee. Arthritis Care \& Research;2012: 64(4), 465-474.

15. Current Care Guidelines (2014) Polvi- ja lonkkanivelrikko (Knee and hip osteoarthritis). Retrieved from http://www.kaypahoito.fi/ web/kh/suositukset/suositus;jsessionid=30 1D0B5375B902FA3C82 BD6D475A79C7?id=hoi50054\#NaN on 28 January 2015.

16. Mas X, Barraquer ME. Gonalgia. Actualización en Medicina de Familia 3[5]. 2013. p. 249-58. 
17. Claudia Lckinger, MBBCh (wits), FCP (SA), Cer Rheum, Mohammed Tikly, MBBCh (wits), et al . Current approach to diagnosis and management of osteoarthritis (July 2010). Division of Rheumatology, Chris Hani , Baragwanath hospital and university of the Witwatersrand, Johannesburg 52: 382-390.

18. Oosterveld FG, Rasker JJ . Treating arthritis with locally applied heat or cold. Semin Arthritis Rheum. 1994; 24: 82-90.

19. Carvalho NA, Bittar ST, Pinto FR, Ferreira M, Sitta RR . Manual for guided home exercises for osteoarthritis of the knee. Clinics (Sao Paulo). 2010; 65: 775-780.

20. Chiranthanut N, Hanprasertpong N, Teekachunhatean $\mathrm{S}$. Thai massage, and Thai herbal compress versus oral ibuprofen in symptomatic treatment of osteoarthritis of the knee: a randomized controlled trial. Biomed Res Int. 2014; 2014: 490512.

21. March L., Amatya B., Osborne R.H. \& Brand C. Developing a minimum standard of care for treating people with osteoarthritis of the hip and knee. Best
Practice and Research. Clinical Rheumatology;2010: 24(1), 121-145.

22. Alami S, Boutron I, Desjeux D, Hirschhorn M, Meric G, Rannou F, Poiraudeau S. Patients' and practitioners' views of knee osteoarthritis and its management: a qualitative interview study. PLoS One. 2011 May 5;6(5):e19634.

23. Walker J. Effective management strategies for osteoarthritis. British Journal of Nursing; 2011:20(2), 81-85.

24. De Haes H. \& Bensing J. Endpoints in medical communication research, proposing a framework of functions and outcomes. Patient Education and Counseling;2009: 74(3), 287-294.

25. Reid DA, Potts G, Burnett M, Konings B. Physiotherapy management of knee and hip osteoarthritis: a survey of patient and medical practitioners' expectations, experiences and perceptions of effectiveness of treatment. Journal of Physiotherapy. 2014;42(2):118-25.

26. Fransen M, McConnell S, Bell $M$. Exercise for osteoarthritis of the hip or knee. Cochrane Database Syst Rev. 2003; : CD004286.

\section{List of Abbreviation}

\begin{tabular}{|l|l|}
\hline Abbreviation & Definition \\
\hline oa & osteoarthritis \\
\hline NSAIDs & Non-steroidal anti-inflammatory drug \\
\hline $\mathrm{n}$ & Sample size \\
\hline $\mathrm{z}$ & level of confidence \\
\hline $\mathrm{p}$ & expected prevalence \\
\hline $\mathrm{d}$ & Precision \\
\hline SFH & Saudi Commission for Health \\
\hline SCFHS & Saudi Commission for Health Specialty \\
\hline
\end{tabular}


Questionnaire:

\section{Appendix I Study questionnaire}

1) Height:

2) Weight:

3) Age:

4) Gender:

$\square$ Male $\square$ female

5) Educational Level

$\square$ Illiterate $\square$ primary school $\square$ secondary school

$\square$ high school $\square$ diploma, bachelor $\square$ Post graduate (Master, PhD...etc.)

6) Occupation

$\square$ Student $\square$ Employed (healthcare professional)

$\square$ Employed (others) $\square$ unemployed $\square$ Retired $\square$ housewives

7) Marital status

$\square$ married $\square$ single $\square$ Divorced $\square$ Widowed

9 ) Do you have one or more of the following chronic diseases?

$\square$ Hypertension $\square$ Dyslipidemia $\square$ diabetes mellitus

$\square$ cardio vascular disease $\square$ obesity

10) Do you have a first degree family history of knee Osteoarthritis?

$\square$ Yes $\square$ No $\square$ Unknown

11) How long have you had symptoms of osteoarthritis?

$\square$ less than 3 years $\square$ 3-5 years $\square 5-10$ years $\square$ more than 10 years

12) From your knowledge, Is there a conservative management for knee osteoarthritis?

$\square$ Yes $\square$ No

If the answer was yes to question (12) please proceed to the next questions

13) If yes what kind of conservative management (you can choose more than one)

$\square$ Weight reduction $\square$ pain killer $\square$ physiotherapy $\square$ Intraarticular injections

14) From your knowledge, does family physician treat knee osteoarthritis?

$\square$ Yes $\square$ No

If the answer was yes to question (14) please proceed to the next questions

15) If yes ,Did your family physician give you any options of conservative management for knee osteoarthritis before?

$\square$ Yes $\square$ No

16) have you ever tried pain killer medications before?

$\square$ Yes $\square$ No

If yes what kind of pain killer?

$\square$ Paracetamol $\square$ NSAID $\square$ OTHERS $($.......)

For how long? :

Is pain improved? : $\square$ Yes $\square$ No

17) have you tried to reduce your weight?

$\square$ Yes $\square$ No

If yes, how much weight did you reduce:

Is pain improved? : $\square$ Yes $\square$ No

18) have you ever tried physiotherapy before?

$\square$ Yes $\square$ No

If yes, for how long: $1 \quad 5 \quad 5-10 \quad$ more than 10 times

Is pain improved? : $\square$ Yes $\square$ No

19) have you ever tried Intraarticular injections before?

$\square$ Yes $\square$ No

If yes, for how many times :

Is pain improved? : $\square$ Yes $\square$ No

20) Did you visit your family physician more than once complaining of the knee pain before he/she referred you to orthopedics?

$\square$ Yes $\square$ No

22) Did your family physician refer you to orthopedics without trying with you conservative management?

$\square$ Yes $\square$ No 


\section{Appendix II Ethical Approval}

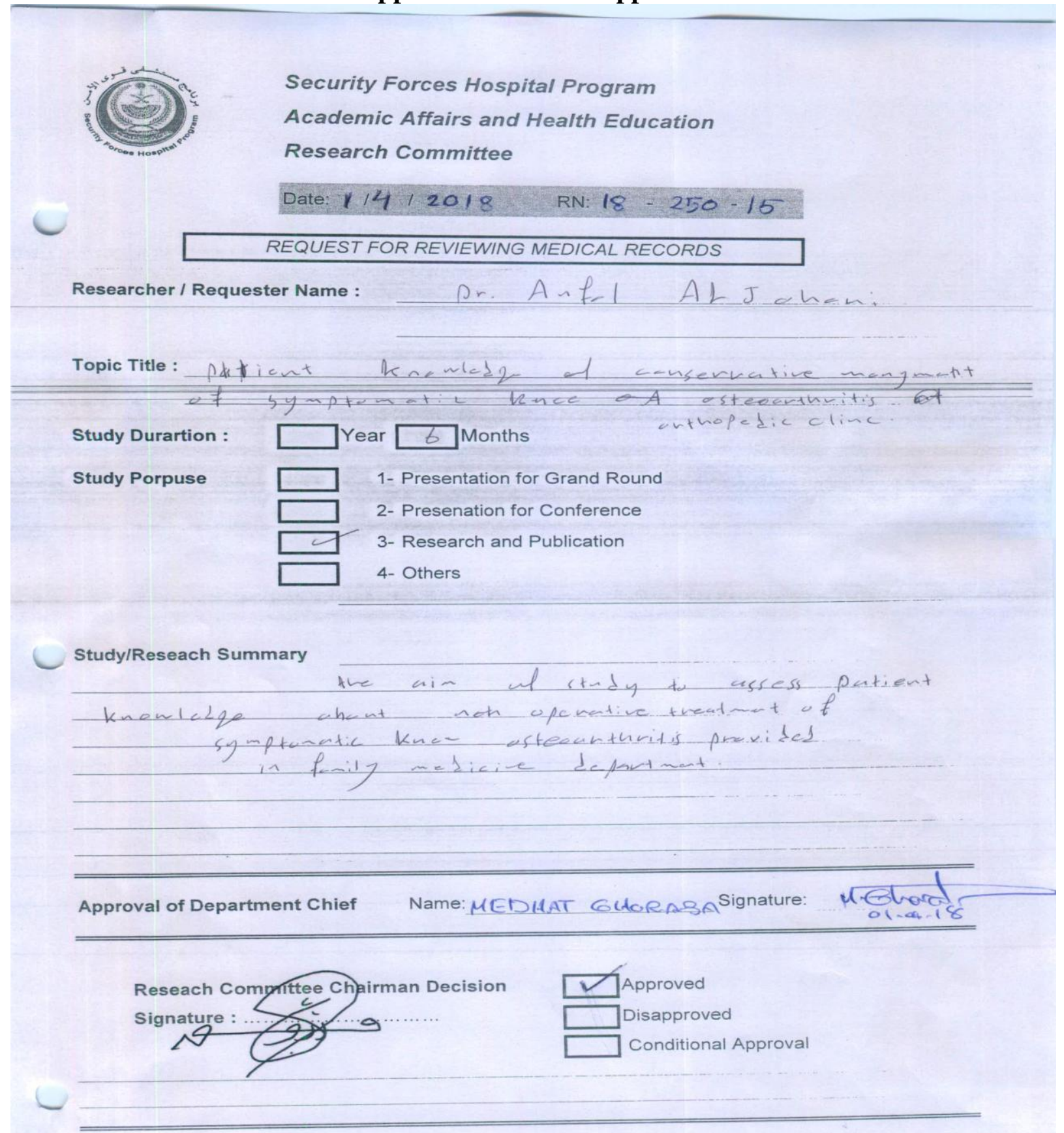

\section{Appendix II C.V}

Personal Data :

Name : Anfal mohammad AlJohani

Nationality : Saudi

Gender : Female

Date of birth : Novmber, $8^{\text {th }}, 1989$

Home address :Qurtuba, Riyadh city , Kingdom of Saudia Arabia

Language : Arabic . English

Contact information :

Mobile number : 00966541142844

Email address : $\underline{\text { dr_anfal@hotmail.com }}$ 
Education

\begin{tabular}{|l|l|}
\hline $\mathbf{2 0 1 5}$ & Family Medicine Resident (SFH) \\
\hline $\mathbf{2 0 1 3 - 2 0 1 4}$ & Internship year, July $1^{\text {st }} 2013-$ June $30^{\text {th }} 2014$ \\
\hline $\mathbf{2 0 1 3}$ & $\begin{array}{l}\text { Bachelor's degree, Faculty of medicine ,King Saud University , Riyadh . } \\
\text { Kingdom of Saudia Arabia }\end{array}$ \\
\hline $\mathbf{2 0 0 7}$ & High School Degree . 79 \\
\hline
\end{tabular}

Exams and licenses taken

2014 Saudi License Exam .

Grade $=83 \%$

Researches

\begin{tabular}{|c|c|}
\hline 2017 & $\begin{array}{c}\text { Patient knowledge of conservative management of symptomatic knee osteoarthritis } \\
\text { at Orthopedic Clinic, in SFHP, Riyadh; (a primary health care prospective) }\end{array}$ \\
\hline $\mathbf{2 0 1 2}$ & $\begin{array}{l}\text { The link between vitamin D and asthma in Saudi Arabia. } \\
\text { Supervised by: Dr. Saleh AlMuhsen }\end{array}$ \\
\hline
\end{tabular}

Conferences

\begin{tabular}{|l|l|}
\hline $\mathbf{2 0 1 2}$ & Internal medicine research day \\
\hline $\mathbf{2 0 1 2}$ & Recent trends in antimicrobial therapy \\
\hline $\mathbf{2 0 1 2}$ & $11^{\text {th }}$ Asia congress of endoscopic and laparoscopic surgery \\
\hline $\mathbf{2 0 1 2}$ & Obesity from cell to human \\
\hline $\mathbf{2 0 1 3}$ & $24^{\text {th }}$ scientific conference of Saudi heart association \\
\hline
\end{tabular}

Courses and Workshops

\begin{tabular}{|l|l|}
\hline $\mathbf{2 0 1 2}$ & Advanced Cardiovascular Life Support course \\
\hline $\mathbf{2 0 1 5}$ & Basic Life Support course \\
\hline $\mathbf{2 0 1 2}$ & The first specialty day \\
\hline $\mathbf{2 0 1 3}$ & Basic clinical and surgical skills day \\
\hline $\mathbf{2 0 1 3}$ & How to read ECG \\
\hline
\end{tabular}

Extra-Curricular Activities

\begin{tabular}{|l|l|}
\hline $\mathbf{2 0 1 2}$ & Participate in patient quality and safety day \\
\hline $\mathbf{2 0 1 2}$ & Participate in Rhinrology research day \\
\hline $\mathbf{2 0 1 2}$ & Communications skills workshops \\
\hline $\mathbf{2 0 1 2}$ & Organizer( $11^{\text {th }}$ Asia congress of endoscopic and laparoscopic surgery) \\
\hline $\mathbf{2 0 1 2}$ & Volunteer in Masdari group \\
\hline $\mathbf{2 0 1 3}$ & Organizer (How to read ECG) \\
\hline $\mathbf{2 0 1 3}$ & Organizer( intern day 2013) \\
\hline $\mathbf{2 0 1 3}$ & Organizer $\left(24^{\text {th }}\right.$ scientific conference of Saudi heart association) \\
\hline
\end{tabular}

